\title{
鉄骨梁破断後の床スラブのバックアップ効果 BACKUP OF FLOOR SLAB FOLLOWING FRACTURE OF STEEL BEAM
}

\author{
桑村＼cjkstart仁*, 杉田朋哉**, 横山幸夫*** \\ Hitoshi KUWAMURA, Tomoya SUGITA and Yukio YOKOYAMA
}

\begin{abstract}
The 1995 Hyogoken-Nanbu Earthquake gave us a lesson that brittle fracture of beam connections may not necessarily knock down steel frames of buildings. This experimental study is purposed to clarify the reasons why steel frames could stand after such serious damage in beams during the earthquake. It was found that the most promising factor which could support the buildings after beam fracture is the backup of reinforced concrete slabs connected to steel beams with studs. Even after complete fracture of beam sections connected to a column, the beam ends could carry negative bending moment by a couple of tensile force in reinforcing bars in the slab and compressive force in the beam's lower flange which has a post-fracture contact with the column.
\end{abstract}

Keywords : fail safe, steel fracture, floor slab, composite beam, earthquake resistance フェイルセーフ，鉄骨破断，床スラブ，合成梁，耐震性能

\section{1.はじめに}

1995年兵庫県南部地震において鉄骨造建築物に脆性破断と呼ばれ る被害が発生した。その中でもっとも多く報告されたのはラーメン 骨組の梁端溶接接合部の破断で, なかには, あるフロアの梁端がす べて破断したものもあっだ)。しかしながら，梁端破断を起こした建 物で倒壞したものは 1 件も報告されていない。

梁端破断が建物の崩壊に繫がらなかった理由は解明されていない が, 文献1)，2）に扔いて次のような推測がなされている。それは，鉄 骨梁が破断したあと, 梁とシアコネクタで緊結されている床スラブ がバックアップ材として働き，骨組の水平耐力をかなり維持するこ とができたというものである。文献1)に示されている説明図をその まま揭載すると，図一1(a)，(b)のよjになる。図の(a)は柱の両側の 梁が破断したあとも，負曲げの側では床スラブ内の鉄筋が引張力を 負担し，下フランジはき裂が閉じてメタルタッチとなり圧縮力を負 担することによって，曲げモーメント抵抗が生じるメカニズムであ る。罒の(b)は破断していない直交梁が床スラブの面外曲げ抵抗に よってねじられ，そのねじりモーメントが柱に伝わり加力面内の曲 げモーメントに変換されることによって地震水平力に抵抗するメ力 ニズムである。

脆性破断に関寸る研究は兵庫県南部地震以降おおいに進展し, 当 面の対策技術が提示されるまでに至っている2)。しかし，このような 新しい設計技術は材料と溶接の品質向上を期待したものであり，既 存の鉄骨造に関しては対策が建てられていない。また，脆性破断に は大きなばらつきがあり，それを設計施工で制御できない面がある ので，脆性破断を完全に防止することは不可能であるという現実も
ある ${ }^{4), 5)}$ 。したがって, 従来の方法で建設された鉄骨ラーメン構造の 建物が梁端の脆性破断によって倒壊しなかったことを究明し，最低 限の安全性を正確に評価するフェイルセーフの手法淿を持っておく
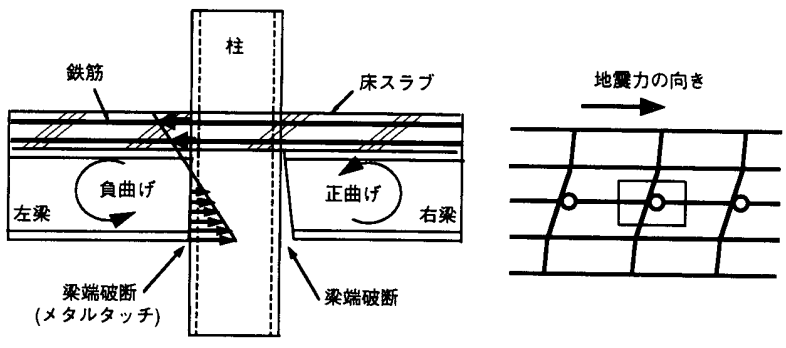

(a) 負曲げに対する抵抗モーメントの発生

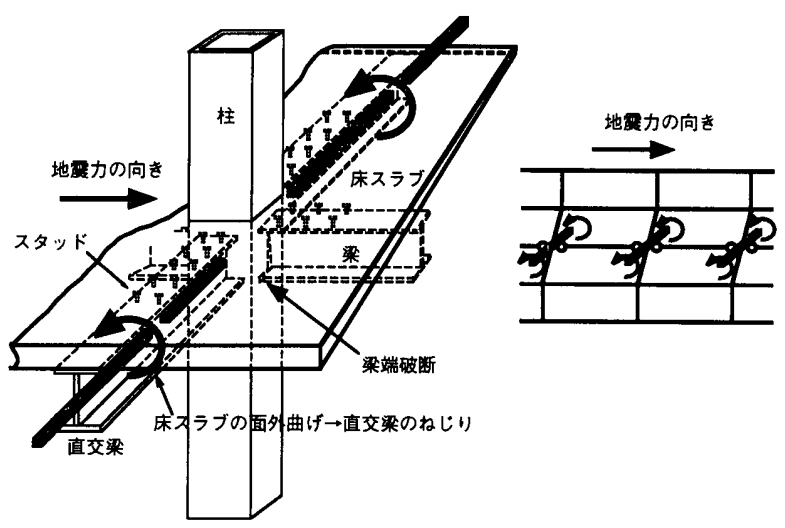

(b) ねじりによる抵抗モーメントの発生

図一1 床スラブが梁端破断後にバックアップとして機能するメカニズム

本論文は，参考文献1，，2）で提起された問題について考究したものである。

* 東京大学大学院工学系研究科建築学専攻 教授.Ph.D

** 東京大学大学院 大学院生・修士 (工学)

*** 駒井鉄工(侏) 博士 (工学)

Prof., Dept. of Architecture, the Univ. of Tokyo, Ph. D.

Grad. Student, the Univ. of Tokyo, M. Eng.

Komai Tekko Inc., Dr. Eng. 
必要がある。この研究は，それを実験的に考究したものである。

\section{2. 実験計画}

\section{1 試験体概要}

本研究で用いた試験体は 2 体で, セットアップ状況とあわせて描 くと, いずれも図一 2 に示寸概形をしている。これはラーメン骨組 の柱 1 本とそれに取り付く 2 方向の梁の半分を約 $1 / 2$ に縮小したも のである。試験体の周辺を支える支柱はその上下ともに梁または基 礎梁とピン接合されており，水平抵抗が生じないようにしてある。 梁の上にはデッキプレートを敷き，スタッドを介して完全合成梁と なるように鉄筋コンクリート床スラブを現場打設した。合成梁の断 面詳細を図一 3 に示す。

$2 つ の$ 試験体の違いは加力方向に直交する梁にスタッドがあるか ないかだけである。これは，上で述べた直交梁のねじり効果を調べ るためである。直交梁にスタッドのあるほうを試験体 1 ，ないほう を試験体 2 と呼ぶことにする。

試験体の柱は角形鋼管で, 梁は $\mathrm{H}$ 形鋼である。柱と梁の接合は剛 接合であるが，破断を意図的に誘発させるために隅肉溶接としてあ ク，さらに載荷方向の梁（以下では単に梁といい，直交梁と区別す る）についてはロータリーグラインダで凹み仕上げを施し有効のど 厚を小さくしている。したがって，梁端はいわゆる保有耐力接合と はなっていない。ただし，直交梁と柱の隅肉溶接には耐力不足が生 じないように凹み仕上げを行っていない。梁端の溶接仕様を困一 4 に示す。なお，梁フランジのレベルには柱に内多イアラムを入れ てある。

載荷方向に対する床スラブの幅は学会指針（各種合成構造設計指 針・同解説）に基づいて計算した有効幅（全有効幅 $945 \mathrm{~mm}$ ）の約 2 倍としてある。スラブ厚はデッキ上端から $60 \mathrm{~mm}$ で, スラブ内の鉄筋 は図一 5 に示すようにD 10 - @100の 2 方向単鉄筋である。鉄筋が柱 とぶつかる部分では，鉄筋が分断されているが，それ以外のところ では 1 本の継手のない鉄筋となっている。

デッキプレート $(t 1.2, h 25)$ は捨型枠として用いた。スタッド(頭 付スタッド $\phi 13 \times L 50)$ は同図一 5 に示すようにピッチ $75 \mathrm{~mm} の 1$ 列配置で，梁フランジの上面に直接スタッド溶接してある。

なお，床スラブ上に積載荷重は載せていない。積載荷重による曲 げモーメシトは, ここで対象としている大地震時の水平力がもたら す曲げモーメントに比べれば小さいと考えてよい。

\section{2 材料の特性}

試験体の梁と直交梁 $(\mathrm{H}-250 \times 125 \times 6 \times 9, \mathrm{SN} 400)$ および柱 $(\square$ $-250 \times 250 \times 16$, STKR 400) の材料引張試験結果を表一 1 に示す。 同じく，鉄筋（D10，SD295）の引張試験結果を表一 2 に示す。

コンクリート（普通コンクリート，呼び強度24）の圧縮試験の結 果を表一 3 に示す。 2 体の試験体はコンクリートを同時に打設した が, 試験日が異なるので（試験体 1 は28日後, 試験体 2 は53日後), それに合わせてコンクリートの圧縮試験を行った。

\section{3 載荷条件}

載荷は, 前出図一 1 に示すように, $300 \mathrm{kN}$ オイルジャッキによる
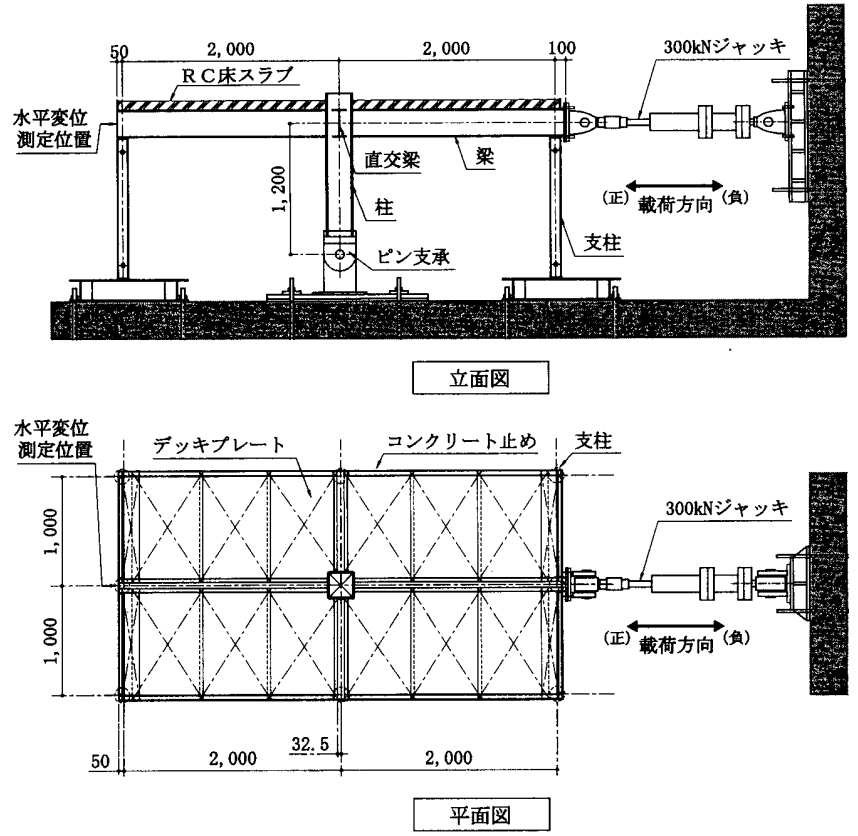

図一２試験体の概形とセットアップ

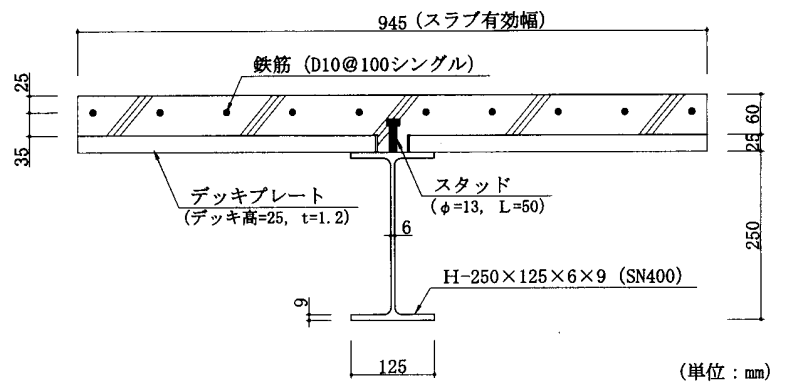

図一 3 合成梁の断面詳細図

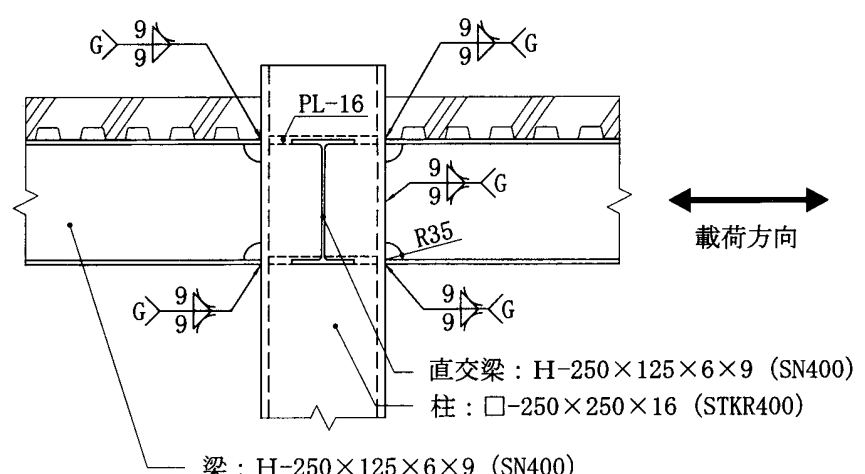

図一 4 梁端の溶接任様

1 方向の繰返し載荷である。梁端が破断する変形量を子め推定する ことが困難であるので，載荷プログラムは設定せず，梁端の破断状 況に応して実験をしながら決めることにした。結果的には，2つの 試験体ともにほぼ等しい変形履歴を与え, 同じ変形量で終了した。 荷重はジャッキ先端のロードセルにより検出し, 水平変位は加力 
点と反対側にある梁端の中心位置で計測し，これを試験体の水平変 形として，後の分析に用いた。

\section{3. 実験結果}

\section{1 荷重一変形履歴曲線}

実験で得られた荷重一変形曲線を図一-6(a)，(b)に示す。(a)は直交 梁にスタッドがある試験体 1 で，(b)は直交梁にスタッドのない試験 体 2 である。図には，梁端の破断状況が合わせて描き込んである。

先ず，(a)について説明する。初期載荷の(2)で正曲げ（下フランジ が引張) となる西側の下フランジが破断し耐力が低下した。除荷後, 逆方向載荷で耐力が上昇する過程の(3)で，今度は正曲げとなる東側 の下フランジが破断し，一時耐力が急降下した。しかし，前に破断 した西側下フランジのクラックが徐々に閉じて剛性が回復し，(4)で ほば全面がメタルタッチとなる。その後, 耐力の上昇が見られ，メ タルタッチした西側下フランジの局部座屈によって最大耐力を迎之 た後, 緩やかに劣化する。劣化過程の(5)で東側梁のウェブにき裂が 進行していくが，耐力の急激な低下は見られない。変位が15センチ ほど進行した時点（層間変形角で約 $1 / 8$ ) で除荷し，再び逆方向に加 カした。初めのうちは，(6のように左右の梁下フランジのき裂が開 いたままであるので, 耐力はほとんど発現しないで変形が進行しい わゆるスリップ形となる。やがて，(7)で負曲げとなる東側の下フラ ンジがメタルタッチとなり, 耐力の回復が始まる。その後, 局部座 風による最大耐力を迎えたあと劣化し，その途中の(8)で正曲げ（西 側）のウェブに進行していたき裂が完全にウェブを貫通する。除荷
後, 逆方向に加力すると, 雨側の梁ともにき裂が開いたままである ので, スリップ形の変形挙動を示す。この途中で実験を終了してい るが，後は，き裂が閉じれば耐力が回復するという同じような履歴 を示すものと考えられる。

困(b)についても図(a)と同様であるが，異なるのは，(a)では上フラ ンジが破断しなかったのに対して，(b)では上フランジの破断も起き ていることである(図の(3)と(7))。このことは，直交梁にスタッドが

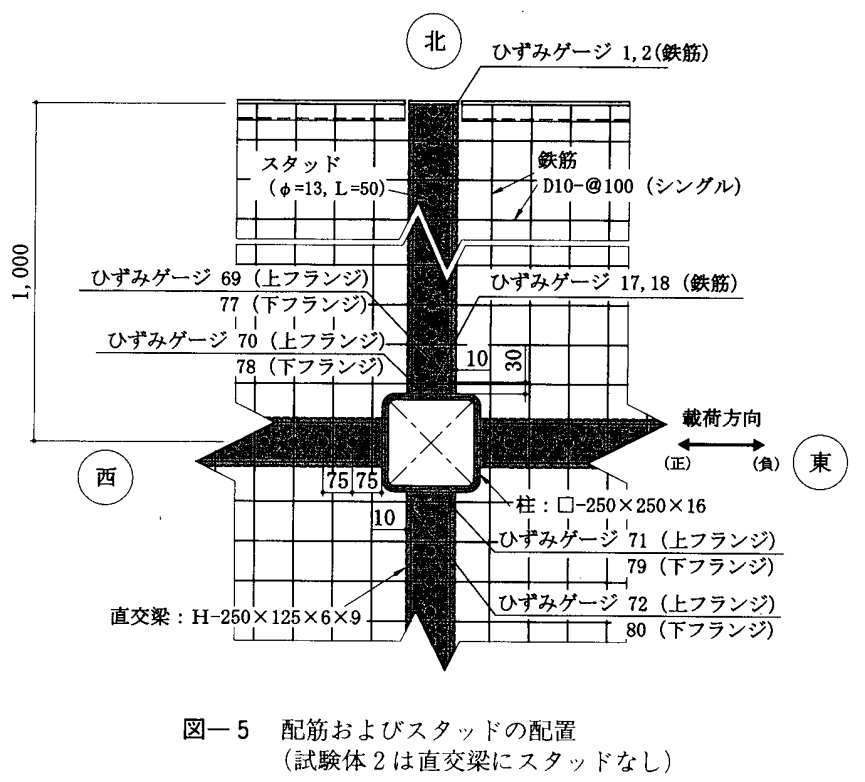

表-1＼cjkstart材料引張試験結果（鋼材）

\begin{tabular}{|c|c|c|c|c|c|c|c|c|}
\hline 部材 & $\begin{array}{c}\text { 断面サイズ } \\
\text { (材質) }\end{array}$ & $\begin{array}{l}\text { 部 位 } \\
\text { (公称板厚) }\end{array}$ & $\begin{array}{l}\text { 試験片 } \\
\text { 番号 }\end{array}$ & $\begin{array}{c}\text { 実測板厚: } \\
\text { [mm }\end{array}$ & $\begin{array}{l}\text { 降伏強さ } \\
{\left[\mathrm{N} / \mathrm{mm}^{2}\right]}\end{array}$ & $\begin{array}{l}\text { 引張強さ } \\
{\left[\mathrm{N} / \mathrm{mm}^{2}\right]}\end{array}$ & $\begin{array}{c}\text { ヤング係数 } \\
{\left[\mathrm{N} / \mathrm{mm}^{2}\right]}\end{array}$ & $\begin{array}{c}\text { 降伏比 } \\
\text { [\%] }\end{array}$ \\
\hline \multirow{4}{*}{ 梁 } & \multirow{4}{*}{$\begin{array}{c}\mathrm{H}-250 \times 125 \times 6 \times 9 \\
(\mathrm{SN} 400)\end{array}$} & \multirow{2}{*}{$\begin{array}{c}\text { フランジ } \\
(\mathrm{t}=9)\end{array}$} & $\mathrm{A}-1$ & 8.8 & 262 & 404 & $1.92 \times 10^{5}$ & 64.8 \\
\hline & & & $\mathrm{A}-2$ & 8.7 & 265 & 414 & $2.07 \times 10^{5}$ & 64.0 \\
\hline & & \multirow{2}{*}{$\begin{array}{c}\text { ウェブ } \\
(\mathrm{t}=6)\end{array}$} & B-1 & 6.0 & 277 & 417 & $1.96 \times 10^{5}$ & 66.6 \\
\hline & & & B-2 & 5.9 & 291 & 423 & $1.92 \times 10^{5}$ & 68.8 \\
\hline \multirow[t]{2}{*}{ 柱 } & \multirow{2}{*}{$\begin{array}{c}\square-250 \times 250 \times 16 \\
(\text { STKR400) }\end{array}$} & \multirow[b]{2}{*}{$(\mathrm{t}=16)$} & $\mathrm{C}-1$ & 15.1 & $403^{* 1}$ & 469 & $1.85 \times 10^{5}$ & 85.8 \\
\hline & & & C-2 & 15.1 & $400 * 1$ & 470 & $1.92 \times 10^{5}$ & 85.0 \\
\hline
\end{tabular}

表一2 材料引張試験結果（鉄筋）

\begin{tabular}{|c|c|c|c|c|c|c|c|}
\hline 部材 & $\begin{array}{c}\text { 公称径 } \\
\text { (材質) }\end{array}$ & $\begin{array}{c}\text { 試験片 } \\
\text { 番号 }\end{array}$ & $\begin{array}{c}\text { 公称断面積 } \\
{\left[\mathrm{mm}^{2}\right]}\end{array}$ & $\begin{array}{c}\text { 降伏強さ } \\
{\left[\mathrm{N} / \mathrm{mm}^{2}\right]}\end{array}$ & $\begin{array}{c}\text { 引張強さ } \\
{\left[\mathrm{N} / \mathrm{mm}^{2}\right]}\end{array}$ & $\begin{array}{c}\text { ヤング係数 } \\
{\left[\mathrm{N} / \mathrm{mm}^{2}\right]}\end{array}$ & $\begin{array}{c}\text { 降伏比 } \\
{[\%]}\end{array}$ \\
\hline 鉄筋 & $\begin{array}{c}\text { D10 } \\
\text { (SD295) }\end{array}$ & $\mathrm{D}-1$ & 71.3 & 347 & 480 & $1.88 \times 10^{5}$ & 70.9 \\
\cline { 5 - 9 } & $\mathrm{D}-2$ & 71.3 & 345 & 479 & $1.93 \times 10^{5}$ & 70.4 \\
\hline
\end{tabular}

表一3 材料試験結果（コンクリート）

\begin{tabular}{|c|c|c|c|c|c|c|}
\hline \multirow[b]{2}{*}{ 部材 } & \multirow[b]{2}{*}{ 材質 } & \multirow[b]{2}{*}{ 材令 } & \multicolumn{2}{|c|}{ 水中盖生 } & \multicolumn{2}{|c|}{ 封縅養生 } \\
\hline & & & $\begin{array}{l}\text { 試験体 } \\
\text { 番号 }\end{array}$ & $\begin{array}{l}\text { 圧縮強度 } \\
{\left[\mathrm{N} / \mathrm{mm}^{2}\right]}\end{array}$ & $\begin{array}{l}\text { 試験体 } \\
\text { 番号 }\end{array}$ & $\begin{array}{l}\text { 圧縮強度 } \\
{\left[\mathrm{N} / \mathrm{mm}^{2}\right]}\end{array}$ \\
\hline \multirow{6}{*}{ スラブ } & \multirow{6}{*}{$\begin{array}{c}\text { 普通コンクリート } \\
\text { (呼び強度 } 24)\end{array}$} & \multirow{3}{*}{ 28日 } & $E_{28} a-1$ & 21.6 & $E_{28} b-1$ & 16.7 \\
\hline & & & $\mathrm{E}_{28} \mathrm{a}-2$ & 17.2 & $E_{28} b-2$ & 17.4 \\
\hline & & & $E_{28} a-3$ & 19.0 & & \\
\hline & & \multirow{3}{*}{ 53日 } & $E_{53} a-1$ & 16.9 & $E_{53} b-1$ & 16.7 \\
\hline & & & $E_{53} a-2$ & 17.4 & $E_{53} b-2$ & 15.8 \\
\hline & & & $E_{53} a-3$ & 17.1 & $\mathrm{E}_{53} \mathrm{~b}-3$ & 16.0 \\
\hline
\end{tabular}




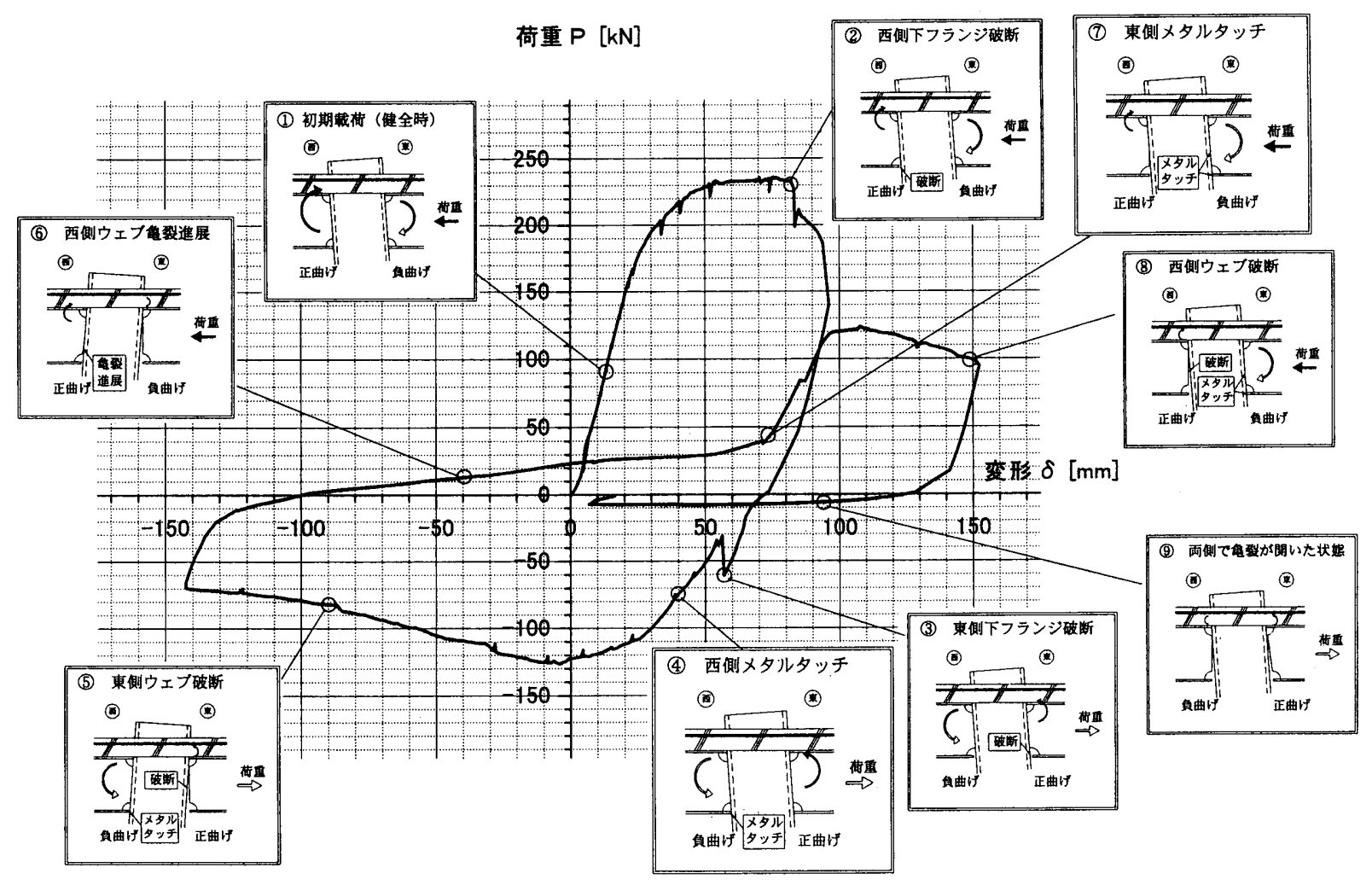

(a) 試験体 1

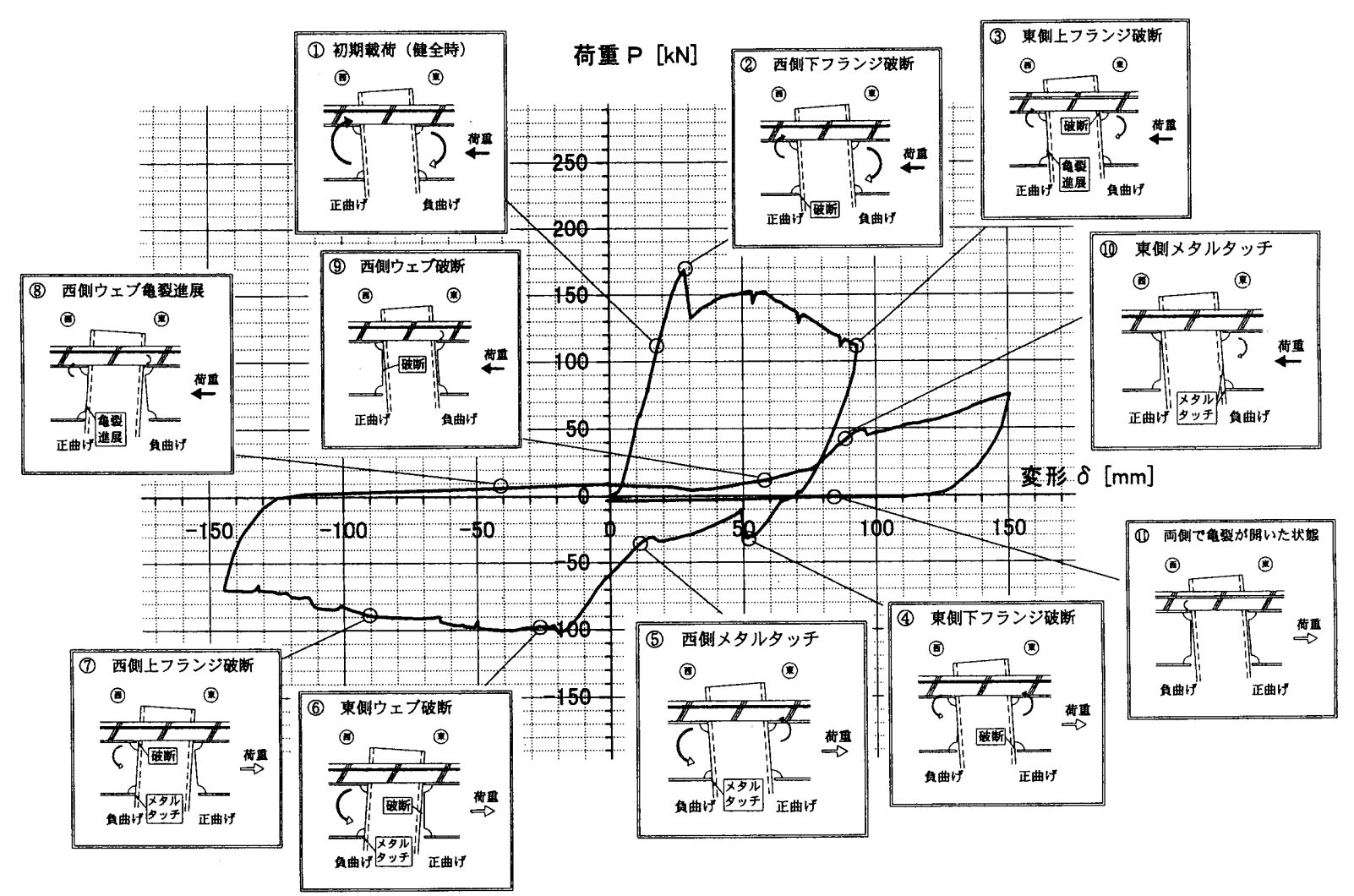

(b) 試験体 2 
なかったのが原因ではなく，梁フランジの隅肉溶接の耐力が異なっ ていたのが決定的な原因と考えられる。上下のフランジが共に破断 したあと，負曲げを下フランジのメタルタッチによる圧縮応力とス ラブ内の鉄筋の引張応力で負担する状況となっているのは, 図の(7) の直後および(10の直後である。この部分では，最大耐力の $30 〜 40 \%$ 程度の耐力を保持していることがわかる。

\section{2 梁端の損傷}

今回の試験体に用いた梁フランジは試験装置の容量の関係で板厚 が比較的薄い $9 \mathrm{~mm}$ である。したがって, 健全な溶接であれば脆性破 断ではなく局部座屈で終局挙動が決まるものである。この研究の目 的は，破断後の床スラブのバックアップ効果を調べることであるの で，意図的に梁端フランジの溶接を不健全な状態，すなわち耐力が 不充分な隅肉溶接とした。したがって，破断は脆性破断ではなく， 写真一 1 (a)，(b)に示すよjに延性破断である。延性破断の場合は, き裂の進行が脆性破断に比べると緩やかであり，ウェブへのき裂も 徐々に進行する。この点が，脆性破断とは異なっているが，床スラ ブが発揮するバックアップのメカニズムには影響を与えないと考之 ることができる。

写真一1 (a)，(b)は試験体 2 の同じ箇所を撮影したものである。(a) は上下のフランジが共に破断した状況で，(b)はその後負曲げの進行 によって下フランジのクラックが閉じてメタルタッチになっている 状況である。

\section{3 床スラブの損傷}

床スラブの損傷状況を上から視たものを試験体 $1 ， 2$ についてそ れぞれ図-7(a)，(b)に示す。いずれも実験終了後のコンクリートの クラックの発生状況を描いている。直交梁にスタッドのある試験体 （図a）とスタッドのない試験体（図b）を比べると, 後者のほうが 曲げひび割れの発生範囲が加力方向（東西方向）に広がっている。 これはスタッドのない試験体では梁の上下フランジがともに破断し たため床スラブの負曲げモーメントの分担がより大きく現れたもの と考之られる。また, 加力直交方向（南北方向）を見ると，床スラ ブの端まで曲げひび割れが進行しており, 計算上の有効幅を超えて 負曲げ状態が広がっていることが観察される。

\section{4. 考 察}

\section{1 床スラブによる負曲げ抵抗}

床スラブによる負曲げ抵抗を鉄筋のひずみ履歴から知ることがで きる。図一8(a)，(b)に2つの試験体それぞれについて柱にもっとも 近い鉄筋ともっとも離れた鉄筋のひずみ履歴を試験体の水平変形を 横軸にとって描いてある(ひずみゲージの位置は図一 5 参照)。カー ブに添った矢印は, 破断した梁下フランジのクラックが閉じメタル タッチになってから鉄筋のUずみが上昇しはじめる部分を表してい る。

直交梁にスタッドがあるかないかにかかわらず，柱に最短距離に ある鉄筋の最大Uずみは約 $0.15 \%$ であり，ほぼ降伏Uずみに達して いる。しかも，これは梁破断後に負曲げ抵抗が発生する状態のとき であり，当初予想した図一1(a)のメカニズムが成立していることが

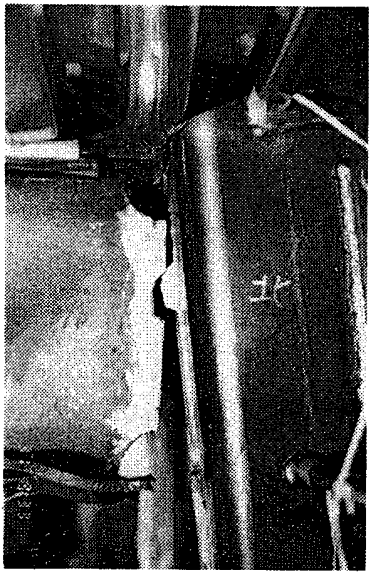

(a) 上下フランジの破断

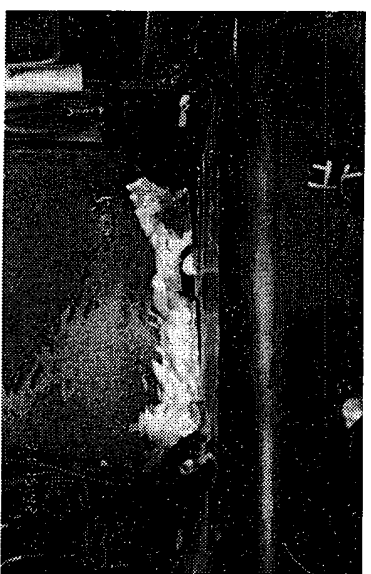

(b) 負曲げによる下フランジの メタルタッチ
写真一 1 梁端破断状況

(北)

西)

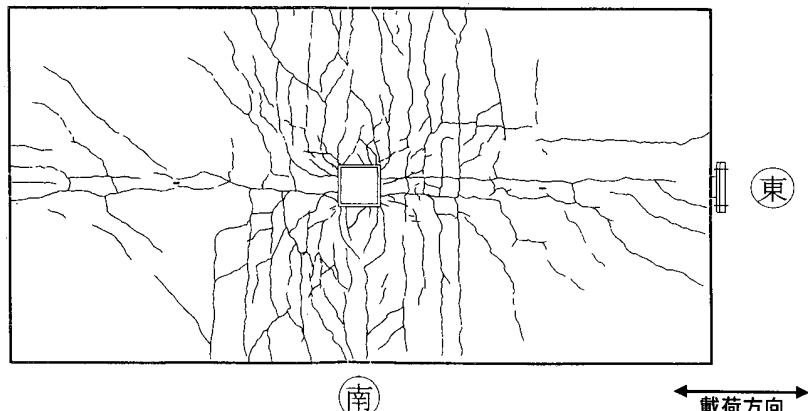

(a) 試験体 1

(北)

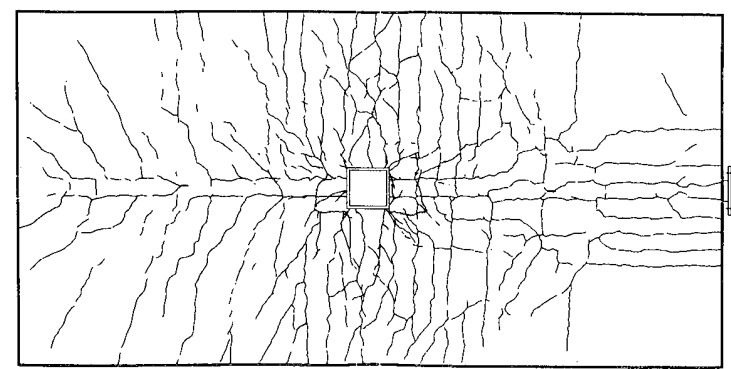

南

$\stackrel{\text { 載荷方向 }}{\longrightarrow}$

(b) 試験体 2

図一7 床スラブのUび割れ状況

確認できる。

柱からもっとも離れた位置すなわち計算上の有効幅から 2 倍離れ た位置における鉄筋のUずみは，2つの試験体ともに最大で約 $0.10 \%$ であり,柱に近接した鉄筋の $2 / 3$ 程度のUずみレベルに達して いる。床スラブに面外曲げ抵抗が生じる範囲はかなり広がるようで ある。 

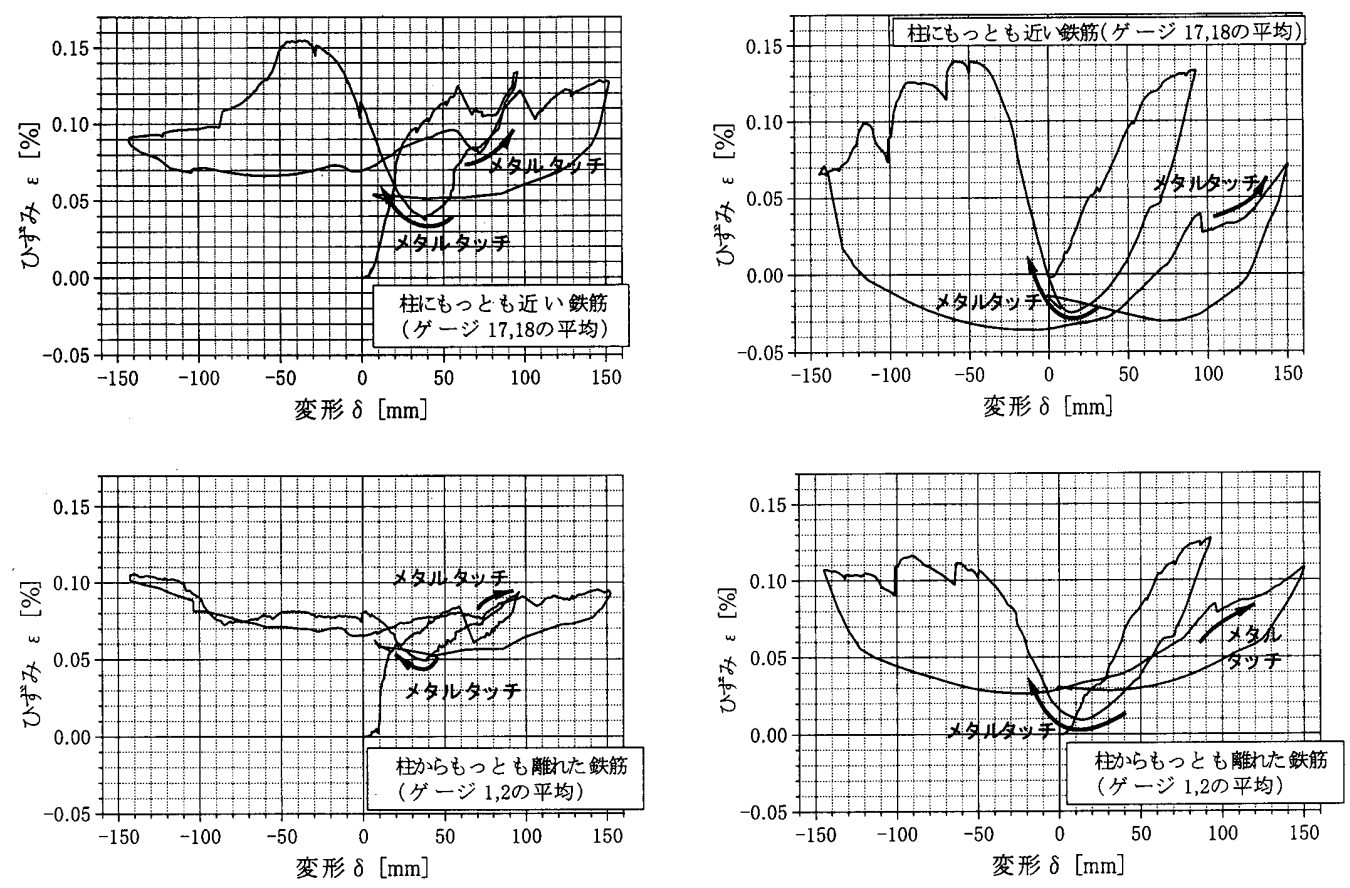

(a) 試験体 1

(b) 試験体 2

图一8 鉄筋のひずみ履歴

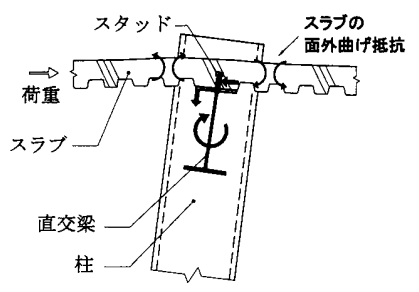

（a）直交梁にスタッドがある場合

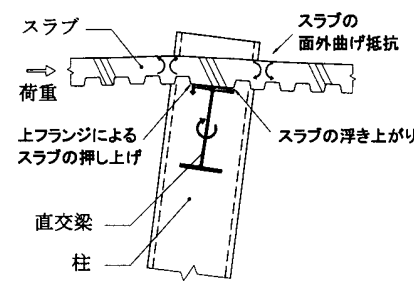

（b）直交梁にスタッドがない場合

図一9 直交梁のねじり

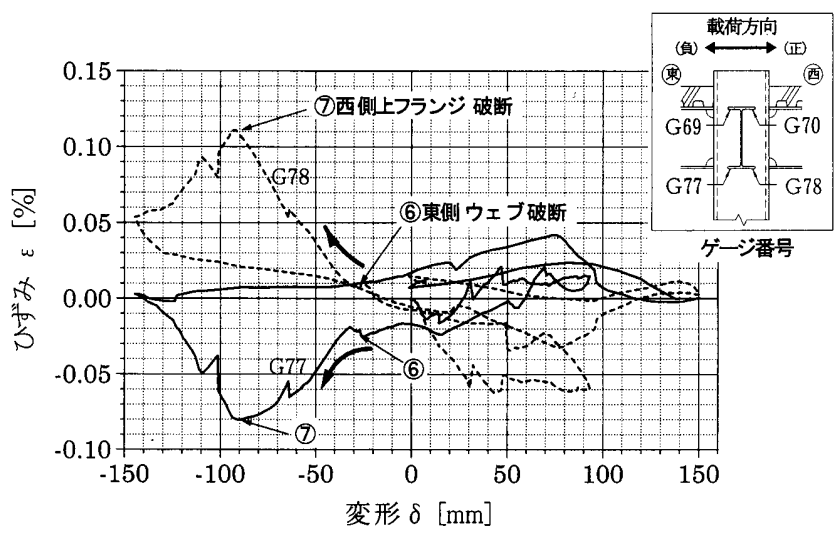

(b-1) 試験体 2 (下フランジ)

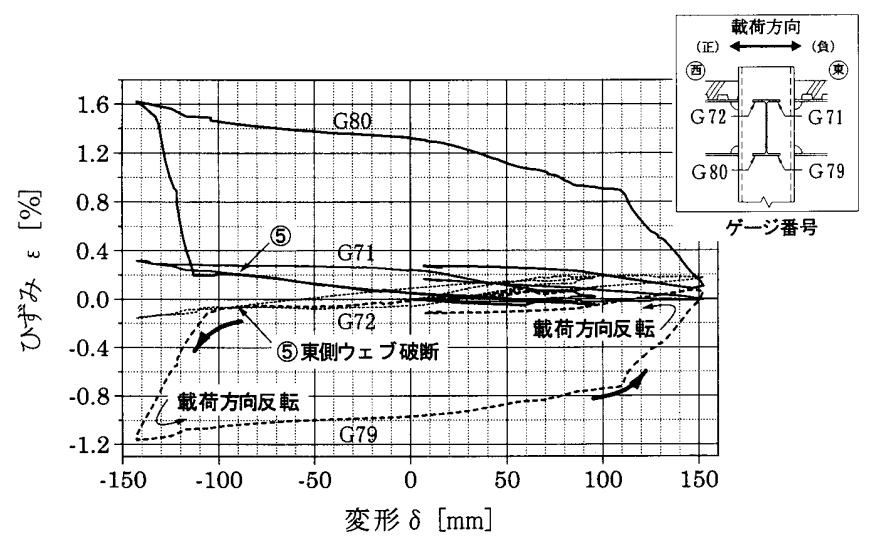

(a) 試験体 1

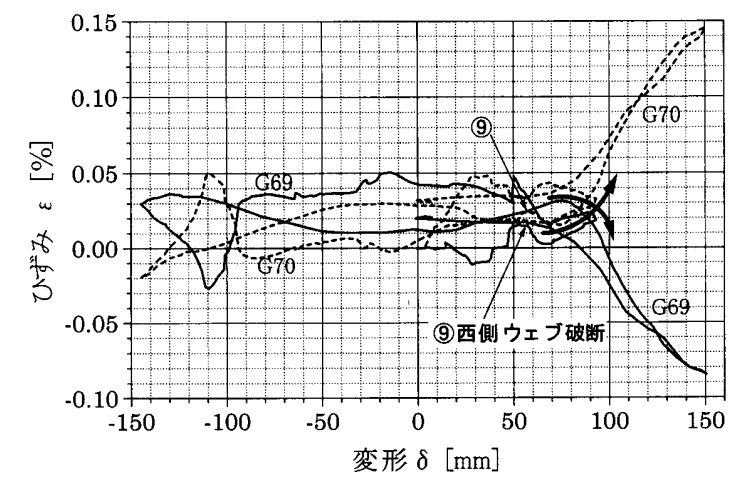

（b-2）試験体 $2 （$ 上フランジ） 


\section{2 直交梁によるねじり抵抗}

図-9(a)に示すよjに，床スラブには面外曲げ抵抗があるのでス タッドで緊結された直交梁はねじられる。すると，材端が柱に溶接 で固定されている直交梁には反りねじりモーメントが発生し, これ によってH形断面をしている直交梁のフランジにはウェブの左右 で逆向きの直応力度が生じる。これを検出するために，直交梁には 前出図一 5 の伏図に示すように，Uずみゲージをフランジに貼付し てある。このひずみ值を骨組の変位に対してプロットしたのが図 -10(a)，(b-1,2)である。

先ず, 図(a)の直交梁にスタッドのある試験体 1 を見ると, 相当大 きな直Uずみが発生している。下フランジのゲージ番号 G80, G79の 最大Uずみは引張 $1.6 \%$ ・圧縮1.2\%にも達し, 反りねじりによって 直交梁端部の下フランジは完全に降伏していることがわかる。しか も，この状態は図に矢印で示すように梁端の破断が下フランジから ウェブまで進行し正曲げ抵抗が失われたときに起こっている。これ は, 梁の正曲げ抵抗が失われると，梁と合成されているスラブも除 荷されフラットになろうとするが，直交梁が柱と同じ傾き角を持っ ているので，スラブと直交梁の変形が適合しようとするために両者 にモーメントの伝達が生じるからである。このことは当初予想して いた図一1(b)のメカニズムが成立していることを示している。

試験体 1 において，直交梁のねじりがもたらす水平抵抗は次のよ うに推定できる。柱の左右の梁端の下フランジとウェブが破断して クラックが開いた状態では載荷方向梁による水平抵抗がほとんど失 われるので直交梁のねじり抵抗のみが現れると考えられる。その状 態は前出図一6(a)の(6)〜(7)の間である。その間，水平変形の増大に 伴って（すなわち柱の倒れ角の増大に伴って）直交梁のねじり抵抗 が増えていると考えると，破断した梁がメタルタッチとなる直前の (7)で約 $40 \mathrm{kN}$ の水平抵抗を発揮していることになる。メタルタッチ 後は負曲げ抵抗が加算され，その最大耐力が約 $120 \mathrm{kN}$ であるので， 負曲げ抵抗の分担は約 $80 \mathrm{kN}$ となる。今回の試験体では負曲げ抵抗 のほうが大きいようであるが，両者を分離することは難しい。参考 に，直交梁のねじりがもたらす最大水平耐力を，直交梁の上下フラ ンジが $\sigma_{y} / \sqrt{3}$ で全断面せん断降伏するときで見積もると, 次式によ り約 $70 \mathrm{kN}$ となる。これが上限であろう。

$$
\frac{A_{f} \times\left(\sigma_{y} / \sqrt{3}\right) \times h}{H} \times 2=68 \mathrm{kN}
$$

$A_{f}$ は片側フランジの断面積で $125 \times 9 \mathrm{~mm}^{2}, \sigma_{y}$ は降伏応力度で 262 $\mathrm{N} / \mathrm{mm}^{2}, h$ は上下フランジの中心間距離で $241 \mathrm{~mm}, H$ は柱の変曲点 高さで $1200 \mathrm{~mm}$ である。

次に, 図(b-1), (b-2)の直交梁にスタッドのない試験体 2 を見る と, 最大Uずみは引張・圧縮で0.1\%前後であり，スタッドのある試 験体よりは小さいが, 応力は降伏応力に近いレベルまで達している。 スタッドがない場合にはスラブと直交梁の間でモーメントの伝達が 生じないように思われるが，実験途中の観察によると，図一9(b)の ようになっており，柱の倒れに伴って傾く直交梁の上フランジが床 スラブを押し上げるため，直交梁にねじりが生じる。これが，フラ ンジのひずみとして検出されたと考えられる。

\section{3 梁端破断後の耐力評価}

上で観察された床スラブによるバックアップのメカニズムに基づ
いて，梁が破断した後の耐力を評価してみる7)このとき，表一4の ように状況を分類する。状態を表す 3 つの数字は，順番に上フラン ジ，ウェブ，下フランジの状況を表し，0が破断していない健全な 状態または破断後にクラックが閉じてメタルタッチになっている状 態を表し，1が破断してクラックが開いている状態を表す。

次の仮定を設けて梁端に破断が生じた合成梁の全塑性曲げモーメ ントを計算する。

1 ）床スラブの有効幅は学会指針で計算される值を採用し，損傷状 況にかかわらず一定とする。

2）鉄骨梁と鉄筋コンクリートスラブで成る合成梁はひずみの平面 保持が成り立つ。

$3)$ 鋼材 (H 梁と鉄筋)およU゙コンクリートは完全弾塑性材料とし, その降伏強さはそれぞれ引張試験による降伏強さと圧縮試験に よる圧縮強さ $\times 0.85$ とする。

4 ）床スラブの有効幅の中にある鉄筋は引張では常に有効，圧縮で はコンクリートが破壊するまで有効に作用する。

5 ）コンクリートは圧縮のみに作用するが，引張ひずみが生じた後 あるいは圧縮Uずみが $0.5 \%$ 超えた後は破壊したとみなし圧 縮に对して効かなくなるものとする。

6 ）梁端が破断してクラックが開いているときは，その部分を無効 とするが,メタルタッチとなると圧縮に対して有効に作用する ものとする。

7 ）水平耐力の計算には載荷方向の梁が破断後に発揮する水平耐力 のみを考慮することとし，直交梁のねじりがもたらす水平耐力 はこれに含まれるものとする。

この仮定に基づいて算定された合成梁の全塑性モーメントを表 ー 5 に示す。今回の試験体では柱の左右が正曲げと負曲げになるの で，これを考慮して試験体の全塑性水平耐力を梁端の損傷状況に応 じて計算し，実験で得られた荷重一変形関係に重ねて描いたのが困

\section{表一 4 梁端の破断状況の分類}

\begin{tabular}{|c|c|c|c|}
\hline 破断記号 & 上フランジ & ウェブ & 下フランジ \\
\hline 000 & $\bigcirc$ & $\bigcirc$ & $\bigcirc$ \\
\hline 001 & $\bigcirc$ & $\bigcirc$ & $\times$ \\
\hline 010 & $\bigcirc$ & $\times$ & $\bigcirc$ \\
\hline 011 & $\bigcirc$ & $\times$ & $\times$ \\
\hline 100 & $\times$ & $\bigcirc$ & $\bigcirc$ \\
\hline 101 & $\times$ & $\bigcirc$ & $\times$ \\
\hline 110 & $\times$ & $\times$ & $\bigcirc$ \\
\hline 111 & $\times$ & $\times$ & $\times$ \\
\hline
\end{tabular}

（○：非破断またはメタルタッチ， $\times$ : 破断）

表一5 破断状況に応じた梁の全塑性モーメント値 $\mathrm{Mp}$

\begin{tabular}{|c|c|c|c|}
\hline \multirow{2}{*}{ 破断記号 } & \multicolumn{2}{|c|}{ 正曲げ } & \multirow{2}{*}{ 負曲げ } \\
\cline { 2 - 3 } & (コンクリート破壊前) & (コンクリート破壊後) & \\
\hline 000 & 162.2 & 82.6 & 117.7 \\
\hline 001 & 74.6 & 33.4 & 48.9 \\
\hline 010 & 114.0 & 71.4 & 87.1 \\
\hline 011 & 23.6 & 0.7 & 15.2 \\
\hline 100 & 146.0 & 33.9 & 89.3 \\
\hline 101 & 55.0 & 11.2 & 46.2 \\
\hline 110 & 95.0 & 0.7 & 71.6 \\
\hline 111 & 3.9 & (耐力なし) & 6.2 \\
\hline
\end{tabular}
( 単位 $: \mathrm{kN} \cdot \mathrm{m}$ ) 


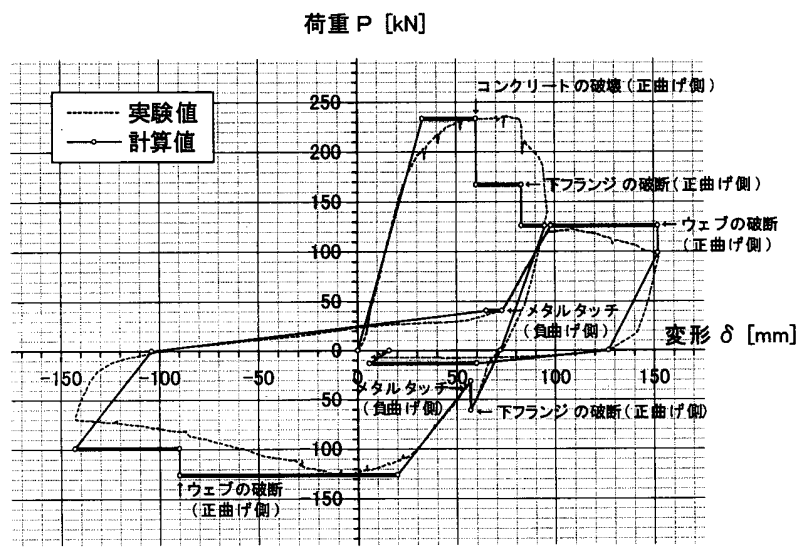

(a) 試験体 1

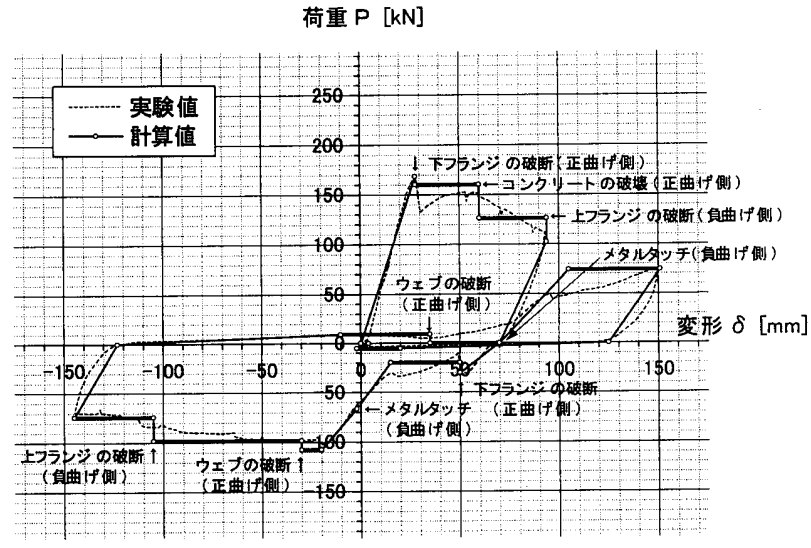

(b) 芸験体 2

図一11 梁端破断後の耐力評価（実験值と計算值の比較）

-11(a)，(b)である。計算で求めたものは全塑性耐力であるので，そ れを繫げた荷重一変形線困は図の実線で示すように階段状となる。 損傷が発生する変形すなわち横座標位置は現在の知見では求めるこ とができないので, 実験での観察点に合わせてあり，負荷と除荷の 剛性も実験カーブに添って描いている。したがって，耐力のレベル (図の水平太実線) だけが実験との比較対象となる。これによると, 各損傷状態における耐力の計算值は実験值と比較的よく合ってお ク，破断後の床スラブによるバックアップのメカニズムが基本的に は定量化されたと考えられる。

\section{5. 結 論}

鉄骨ラーメン構造において, 地震水平力によって梁端が破断した あとの床スラブを含んだ耐力の発現機構について実験を行ったとこ ろ次のことがわかった。

1) 梁端が破断したあと，負曲げ側では下フランジのき裂が閉じて 柱と接触し压縮抵抗が生まれる。それと同時に，床スラブ内の 鉄筋は引張抵抗を発揮する。両者が偶力をなし，梁端破断後も 水平力に対してモーメント抵抗が発現する。

2 ) 床スラブの面外曲げ抵抗は直交梁のねじりモーメントを生み, これが柱に伝わることによって，骨組の水平抵抗が生まれる。

3 ）梁端破断の状態に応じて決まる合成梁の正曲げおよび負曲げの 全塑性耐力を用いて骨組の水平耐力を計算した。これには直交 梁のねじり抵抗は含んでいないが, 結果的には実験值を比較的 良好な精度で予測できた。ただし，骨組の状況（例えば，直交 梁と載荷方向梁の断面サイズのバランスや直交梁と床スラブ厚 とのバランス等）によっては耐力の評価精度が異なってくる可 能性があるので，載荷方向梁と直交梁との耐力分担についてさ らに検討が必要と考之られる。

今回の研究では, 梁端が破断した後の床スラブのバックアップの 仕組みがわかっただけで，それが骨組の地震応答挙動や耐震安全性
にどの程度関わるかについては不明である。今後の課題としたい。

\section{謝 辞}

本研究におけるスラブ付き骨組の載荷実験は東京大学工学部附属 総合試験所大形構造物試験室の試験台で行った。同試験室は 2000 年 9 月をもって廃止され，この実験が最後どなった。長年にわたり実 験を支援して下さった試験室技官の伊藤俊男・掛川保富両氏に謝意 を表します。また, この研究にあたって, 文部省科学研究費基盤研 究 $\mathrm{A}$ 「高層建築鉄骨の脆性破壊の防止技術に関寸る研究」(研究代表 者：桑村 仁)の補助を受けた。

\section{参考文献}

1）桑村 仁：破断する建築骨組の地震応答と崩壊を防止する对策, 日本建築 学会関東支部シンポジウム『鉄骨構造の耐震安全性向上を目指して』, pp. $17-24,1998.3$

2）桑村 仁：鉄骨の脆性破断に対する当面の対策技術, 日本建築学会大会パ ネルディスカッション『鉄骨の破断現象はどこまで解明されたか，当面の 対策技術』，pp.95-111，2000.9

3）日本建築学会：『阪神・淡路大震災調查報告（建築編一 3 ）』，1997.10, 丸 善

4）桑村 仁，伊山 潤，松井康治：鉄骨の脆性破断に及ばす材料靸性と板厚 の影響一鉄骨破断に関する研究 その 1 -, 日本建築学会構造系論文集, No. 525, pp.109-116, 1999.11

5）桑村 仁，高木直人，松井康治：鉄骨の脆性破断に及ぼす溶接入熱の影響 一鉄骨破断に関する研究 その 2 一，日本建築学会構造系論文集，No. 531, pp.157-164, 2000.5

6）伊山 潤, 桑村 仁：地震に対するフェイルセーフ構造, 日本建築学会構 造系論文集，No.507，pp.29-34，1998.5

7）杉田朋哉, 桑村 仁：鉄骨梁の脆性破断に及ぼす $\mathrm{RC}$ 床スラブの合成効 果, 日本建築学会大会学術講演梗概集 (東北), No. 22256, pp.511-512, 2000.9

(2000年 12 月 10 日原稿受理， 2001 年 4 月 18 日採用決定 